\title{
Purification and properties of extracellular lipase from Pseudomonas aeruginosa EF2
}

\author{
E. JANE Gilbert, ${ }^{1}$ Alex Cornish ${ }^{2}$ and Colin W. Jones ${ }^{1 *}$ \\ ${ }^{1}$ Department of Biochemistry, University of Leicester, Leicester LE1 7RH, UK \\ ${ }^{2}$ Shell Research, Sittingbourne ME9 8AG, UK
}

(Received 15 March 1991; revised 15 May 1991; accepted 24 May 1991)

\begin{abstract}
Extracellular lipase was purified from a Tween 80-limited continuous culture of Pseudomonas aeruginosa EF2 by ultrafiltration of the culture supernatant followed by anion-exchange and gel-filtration FPLC. The lipase was composed of a single subunit $\left(M_{\mathrm{r}} 29000, \mathrm{pI} 4.9\right)$, which was capable of a variable degree of aggregation, and which exhibited both lipase activity, measured with the insoluble substrate olive oil (predominantly triolein), and esterase activity, measured with the soluble substrates $p$-nitrophenyl acetate and Tween 80 . Lipase activity was approximately eight times higher than either type of esterase activity ( $k_{\text {cat }}$ approximately $3000 \mathrm{~s}^{-1}$ for the hydrolysis of olive oil). The enzyme showed a marked regiospecificity for the 1,3-oleyl residues of radiolabelled triolein, was relatively stable at moderate temperatures (exhibiting a biphasic loss of activity with an initial $t_{1}$ of $17.5 \mathrm{~min}$ at $60^{\circ} \mathrm{C}$ ) and was very stable to freezing and thawing. Lipase activity was only weakly inhibited by the serine-active reagent 3,4-dichloroisocoumarin, and was not inhibited by the chelating agent EDTA $(1 \mathrm{mM})$. The $\mathrm{N}$ terminal amino acid sequence of the Ps. aeruginosa EF2 lipase showed a marked similarity to those of several other bacterial lipases.
\end{abstract}

\section{Introduction}

Recent interest in the potential use of microbial lipases in biotechnology (see Macrae, 1983; Macrae \& Hammond, 1985; Harwood, 1989) has stimulated work on the purification and characterization of several of these enzymes from bacteria, principally from mesophilic and psychrotrophic species of Pseudomonas (Dring \& Fox, 1983; Fox \& Stepaniak, 1983; Stuer et al., 1986; Yamamoto \& Fujiwara, 1988). Most of these lipases are particularly thermolabile at moderate temperatures and/or are inhibited by chelating agents: both properties may limit the potential applications of these enzymes for detergent formulations.

Pseudomonas aeruginosa strain EF2 is a newly-isolated, thermotolerant bacterium which produces an extracellular lipase. The physiological regulation of lipase expression by this organism, and the optimization of lipase production during growth in continuous culture, have recently been reported (accompanying paper: Gilbert $\boldsymbol{e t}$ al., 1991).

This paper describes the purification of the $P s$.

Abbreviations: DCI, 3,4-dichloroisocoumarin; FPLC, fast protein liquid chromatography. aeruginosa EF2 lipase together with some of its biochemical and physicochemical properties.

\section{Methods}

Organism and culture conditions. Pseudomonas aeruginosa EF2 was grown in continuous culture under Tween 80 (polyoxyethylene sorbitan monooleate) limitation (dilution rate, $D 0.05 \mathrm{~h}^{-1}, \mathrm{pH} 6.5,37^{\circ} \mathrm{C}$ ) as described previously (Gilbert et al., 1991).

Preparation of culture supernatants. Cultures were harvested by centrifugation in an MSE high-speed centrifuge at $10000 \mathrm{~g}$ for $15 \mathrm{~min}$, and the supernatant was carefully removed and stored at $-20^{\circ} \mathrm{C}$ until required.

Purification of lipase. The culture supernatant $(697 \mathrm{ml})$ was reduced in volume to approximately $10 \mathrm{ml}$ by passage under nitrogen at $4{ }^{\circ} \mathrm{C}$ through a 202 Ultrafiltration unit (Amicon) containing a YM10 $\left(M_{\mathrm{r}}\right.$ 10000 ) cut-off filter. Excess salts were removed by passage through a PDI0 desalting column (Pharmacia) to give a final volume of $14 \mathrm{ml}$. The concentrated, desalted supernatant was passed through an acrodisc filter ( $0.2 \mu \mathrm{m}$ pore size; Gelman), then loaded on to an FPLC 10/10 Mono-Q anion-exchange column (Pharmacia) equilibrated with $20 \mathrm{~mm}$-Tris/ $\mathrm{HCl}$ buffer, $\mathrm{pH} 7.5$, and eluted with the same buffer containing a linear gradient of $\mathrm{NaCl}(0-1 \mathrm{M}$ over $40 \mathrm{~min})$ at a flow rate of $3 \mathrm{ml} \mathrm{min}{ }^{-1}$. The seven fractions containing the highest lipase activities were pooled, then concentrated by passage under nitrogen at $4^{\circ} \mathrm{C}$ through an 8010 Ultrafiltration unit (Amicon) containing a PM10 $\left(M_{\mathrm{r}} 10000\right)$ cut-off filter and centrifuged at full speed for $10 \mathrm{~min}$ in a 
Microcentaur centrifuge (MSE). The supernatant was divided into two $0.75 \mathrm{ml}$ portions, each of which was loaded on to an FPLC Superose 6 gel-filtration column (Pharmacia) and eluted at a flow rate of $0.25 \mathrm{ml}$ min $^{-1}$ with $20 \mathrm{~mm}-\mathrm{Tris} / \mathrm{HCl}$ buffer, $\mathrm{pH} 7.5$, containing $100 \mathrm{mM}-\mathrm{NaCl}$. The fractions containing the highest lipase activities were analysed by SDS-PAGE, and those which contained pure lipase were pooled and stored at $-20^{\circ} \mathrm{C}$.

Enzyme assays. Lipase activity was assayed titrimetrically at $\mathrm{pH} 9 \cdot 0$ with a standard olive oil emulsion as substrate (Sigma), and esterase activity was assayed spectrophotometrically at $\mathrm{pH} 7.0$ with $p$ nitrophenyl acetate as substrate, both at $37^{\circ} \mathrm{C}$, as described previously (Gilbert et al., 1991). Esterase activity was also measured titrimetrically at $\mathrm{pH} 9.0$ and $37^{\circ} \mathrm{C}$, as described for lipase, except that the olive oil emulsion was replaced by $20 \%(\mathrm{v} / \mathrm{v})$ Tween 80 as substrate. In some experiments lipase and esterase (Tween 80 ) activities were measured at a series of $\mathrm{pH}$ values over the range 7.0 to 10.5 , and temperatures over the range 20 to $70^{\circ} \mathrm{C}$. Lipase activity was expressed as lipase units (LU) (mg cells $)^{-1}$ or LU (mg protein $)^{-1}$ (1 LU was defined as the release of $1 \mu \mathrm{mol}$ titratable fatty acid per min). Esterase activities were expressed as $\mu \mathrm{mol} \mathrm{min}^{-1}$ (mg cells) ${ }^{-1}$ or $\mu \mathrm{mol} \mathrm{min}^{-1}$ (mg protein) $)^{-1}$.

Inhibition of lipase and esterase activity by DCI. The effect of the serine-active reagent 3,4-dichloroisocoumarin (DCI) on the activity of the purified lipase was determined by incubating the enzyme (approximately $20 \mathrm{\mu g} \mathrm{m}^{-1}$ ) at $30^{\circ} \mathrm{C}$ in $20 \mathrm{~mm}$-Tris/ $\mathrm{HCl}$ buffer, $\mathrm{pH} 7.5$, containing up to $100 \mu \mathrm{M}-\mathrm{DCI}$ (added from a $10 \mathrm{~mm}$ stock solution in methanol). Small samples of the mixture removed over a $3.5 \mathrm{~h}$ period and assayed for lipase and esterase (Tween 80) activity. Control samples were assayed for the effect of methanol alone.

Determination of regiospecificity. This was carried out at $37^{\circ} \mathrm{C}$ using a modification of the method of Okumura et al. (1976). For qualitative analysis the reaction mix (final volume $2.5 \mathrm{ml}$ ) contained $2.15 \mathrm{ml}$ $20 \mathrm{~mm}-\mathrm{Tris} / \mathrm{HCl}$ buffer, $\mathrm{pH} 7.5$, containing $250 \mathrm{~mm}-\mathrm{NaCl}$ and $50 \mathrm{~mm}$ $\mathrm{CaCl}_{2}, 0.25 \mathrm{ml}$ triolein $(99 \%$ pure) or diolein $(85 \%$ 1,3-diolein, $15 \%$, 1,2-diolein), and $0.1 \mathrm{ml}$ purified lipase. Identical mixes were placed in several $10 \mathrm{ml}$ glass scintillation vials and agitated at $37^{\circ} \mathrm{C}$. Each reaction was started by the addition of enzyme to a final concentration of approximately $20 \mu \mathrm{g} \mathrm{ml}^{-1}$, and terminated at intervals up to $7 \mathrm{~h}$ by three successive extractions into $2.5 \mathrm{ml}$ dichloromethane. The solvent was then removed by rotary evaporation, and the residue was resuspended in $2.5 \mathrm{ml}$ dichloromethane. Samples $(1 \mu \mathrm{l})$ were applied to a $0.25 \mathrm{~mm}$ thick silica gel $60 \mathrm{~F}-254$ chromatography plate, and were resolved in a 70:30:1 (by vol.) mix of ligroin (mineral spirits)/diethyl ether/acetic acid. The spots were visualized by spraying the plate with $20 \%(\mathrm{v} / \mathrm{v}) \mathrm{H}_{2} \mathrm{SO}_{4}$ in ethanol and then heating in an oven at $100{ }^{\circ} \mathrm{C}$ until charring occurred, and were identified by comparing their $\boldsymbol{R}_{F}$ values with those of known standards. For quantitative analysis the procedure used was as described above except that the substrate consisted of $0.25 \mathrm{ml}^{1+} \mathrm{C}$-labelled triolein (glycerol tri[ $[1-1+\mathrm{C}]$ oleate; $12 \mathrm{mCi} \mathrm{mmol}^{-1}$,
$0.44 \mathrm{GBq} \mathrm{mmol}^{-1}$ ) and $2 \mu \mathrm{l}$ samples were applied to the chromatography plate. After separation, the spots were scraped off the plate and placed in plastic vials containing $4 \mathrm{ml}$ Optiphase $\mathrm{T}$ scintillation fluid prior to measuring the radioactivity by scintillation counting.

Non-dissociating (native)-PAGE. Discontinuous native-PAGE was carried out at high $\mathrm{pH}$ (stacking gel $\mathrm{pH} 8 \cdot 3$, running gel $\mathrm{pH} 9.5$ ) using $7 \cdot 5 \%(\mathrm{w} / \mathrm{v})$ polyacrylamide slab gels (Hames, 1981$)$ which were stained for protein using Kenacid blue R. Staining for lipase activity was carried out by incubating the gel at $37^{\circ} \mathrm{C}$ for $24 \mathrm{~h}$ in contact with a $1 \%$ (w/v) agarose overlay attached to 1850-101 Gel Bond Film (LKB). The overlay contained either $(a)$ a $5 \%(\mathrm{v} / \mathrm{v})$ olive oil emulsion (Sigma) containing $0.01 \%(\mathrm{w} / \mathrm{v})$ Victoria blue $\mathrm{B}$, or $(b) 2 \%(\mathrm{v} / \mathrm{v})$ Tween 80 plus $3 \mathrm{mM}-\mathrm{CaCl}_{2}$ in $50 \mathrm{mM}-\mathrm{Tris} / \mathrm{HCl}$ buffer, $\mathrm{pH} 8.5$, and lipase activity was detected by the appearance of, respectively, a blue zone on a white background (due to the release of oleic acid and its interaction with the $\mathrm{pH}$ indicator) or of a white zone on a clear background (due to the precipitation of calcium oleate).

Other methods. Discontinuous SDS-PAGE and determination of protein using the Bradford method was carried out as described previously (Silman et al., 1989; Gilbert et al., 1991). The gels were stained for protein with Kenacid blue $\mathbf{R}$, then destained and, where appropriate, scanned at $633 \mathrm{~nm}$ using an LKB laser densitometer linked to a recording integrator. Determination of the $\mathrm{N}$-terminal amino acid sequence and the $\mathrm{pI}$ value of the purified lipase was carried out using previously described procedures (Silman et al., 1991).

Chemicals. $\left[{ }^{14} \mathrm{C}\right]$ Triolein (glycerol tri $\left[1-{ }^{14} \mathrm{C}\right]$ oleate; $60 \mathrm{mCi} \mathrm{mmol}^{-1}$, $2.22 \mathrm{GBq} \mathrm{mmol}{ }^{-1}$ ) was purchased from Amersham. All other chemicals were obtained from Sigma or BDH and were of the finest grade available.

\section{Results}

\section{Purification and characterization of lipase}

Ps. aeruginosa EF2 was grown in Tween 80-limited continuous culture under near-optimum conditions for expression of maximum lipase activity $\left(D 0.05 \mathrm{~h}^{-1}\right.$, $\mathrm{pH} 6.5,37^{\circ} \mathrm{C}$ ), and the lipase was purified from the culture supernatant by ultrafiltration followed by anionexchange (Mono-Q) and gel-filtration (Superose) FPLC (Table 1, Fig. 1). SDS-PAGE followed by scanning densitometry showed that the enzyme was $99.5 \%$ pure. The calculated purification factor of 31 indicated that the lipase concentration in the culture supernatant was approximately $2 \mu \mathrm{g} \mathrm{ml}^{-1}$ (equivalent to approximately

\section{Table 1. Purification of extracellular lipase from Ps. aeruginosa EF2}

Lipase was purified from the culture supernatant of a Tween 80-limited continuous culture of Ps. aeruginosa EF2 $\left(D 0.05 \mathrm{~h}^{-1}, \mathrm{pH} \mathrm{6.5,37}{ }^{\circ} \mathrm{C}\right)$. The supernatant was concentrated by ultrafiltration and the lipase was subsequently purified using anion-exchange (Mono-Q) and gel-filtration (Superose) FPLC as described in Methods.

\begin{tabular}{|c|c|c|c|c|c|c|}
\hline Fraction & $\begin{array}{c}\text { Protein } \\
\text { concentration } \\
\left(\mathrm{mg} \mathrm{ml}^{-1}\right)\end{array}$ & $\begin{array}{l}\text { Total } \\
\text { protein } \\
(\mathrm{mg})\end{array}$ & $\begin{array}{c}\text { Specific } \\
\text { activity } \\
\left(L U \mathrm{~m}^{-1}\right)\end{array}$ & Purification & $\begin{array}{l}\text { Total } \\
\text { activity } \\
\text { (LU) }\end{array}$ & $\begin{array}{c}\text { Yield } \\
(\%)\end{array}$ \\
\hline Supernatant & 0.07 & $48 \cdot 8$ & 213 & $1 \cdot 0$ & 10406 & 100 \\
\hline Concentrated supernatant & 1.43 & $20 \cdot 0$ & 468 & $2 \cdot 2$ & 9377 & 90 \\
\hline Mono-Q & 1.75 & $5 \cdot 4$ & 1226 & $5 \cdot 7$ & 6650 & 64 \\
\hline Superose & 0.02 & $0 \cdot 28$ & 6606 & $31 \cdot 0$ & 1853 & 18 \\
\hline
\end{tabular}




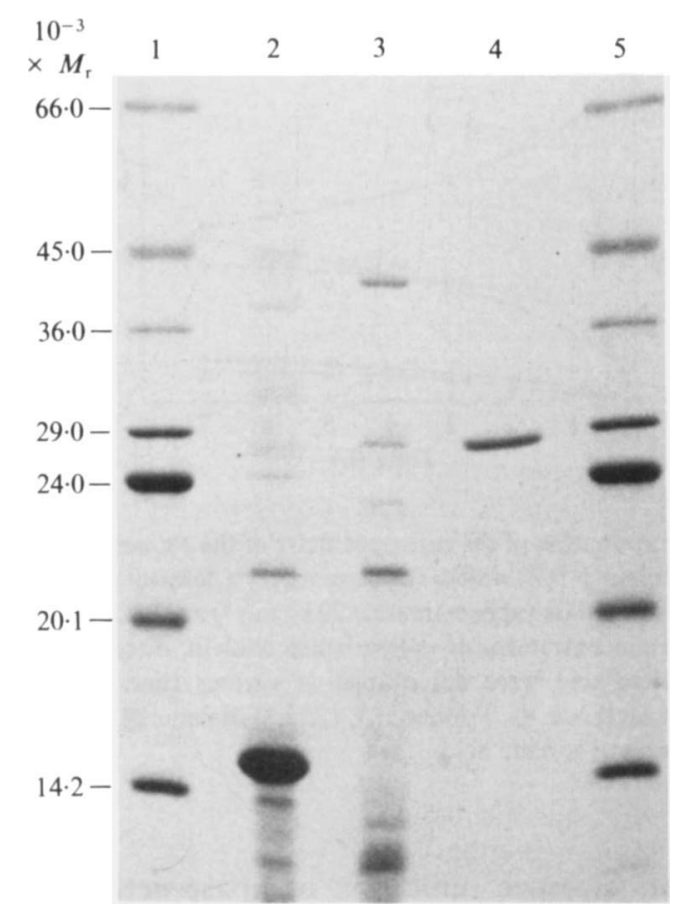

Fig. 1. SDS-PAGE showing the purification of lipase from a culture supernatant of Ps. aeruginosa EF2 grown under Tween 80 limitation. Proteins were separated using SDS-PAGE and stained with Kenacid blue $\mathrm{R}$ as described in Methods. Tracks: 1, $M_{\mathrm{r}}$ standards; 2, concentrated culture supernatant; 3, pooled Mono-Q fractions; 4; pooled Superose fractions; $5, M_{\mathrm{r}}$ standards.

$3 \%$ of the total protein). However, subsequent purifications using identical FPLC procedures showed that the purification factor was extremely variable and could be as low as 5 (equivalent to approximately $20 \%$ of the protein in the culture supernatant). This variation presumably reflected the difference, albeit slight, in the extent of cell lysis in the various cultures.

SDS-PAGE showed that the lipase was composed of a single type of subunit with an $M_{\mathrm{r}}$ of approximately 29000. Gel-filtration FPLC on a Superose column, precalibrated with various $M_{\mathrm{r}}$ standards, indicated that the enzyme was capable of undergoing variable but extensive aggregation, which was subsequently confirmed by the observation that the enzyme smeared badly when subjected to native-PAGE. In spite of this, isoelectric focusing of the lipase on non-dissociating polyacrylamide gels led to sufficiently clear focusing of the enzyme to indicate an isoelectric point (pI) of $4 \cdot 9$, a value which was commensurate with the ability of the enzyme to bind to the anion-exchange resin (Mono-Q) during FPLC.

The purified enzyme exhibited both lipase activity, measured with olive oil (predominantly triolein) as substrate, and esterase activity, measured with $p$ - nitrophenyl acetate and Tween 80 as substrates, confirming an earlier suggestion based on the physiological studies that both activities were expressed by a single enzyme (Gilbert et al., 1991). Lipase activity was significantly enhanced by the presence of $\mathrm{NaCl}$ (optimum concentration $250 \mathrm{mM}$ ) and/or $\mathrm{CaCl}_{2}$ (optimum concentration $50 \mathrm{mM}$ ). The lipase activity of the purified enzyme from Ps. aeruginosa EF2 was $6606 \mathrm{LU} \mathrm{mg}^{-1}$ (assayed at $\mathrm{pH} 9.0,37^{\circ} \mathrm{C}$ ) which was equivalent, assuming a minimum native $M_{\mathrm{r}}$ of 29000 , to a $k_{\text {cat }}$ of $3193 \mathrm{~s}^{-1}$. The lipase activity was approximately eight times the esterase activities obtained with $p$-nitrophenyl acetate and Tween 80 , indicating that the enzyme is much more active on an olive oil emulsion than on the two soluble substrates tested, and that it should therefore be regarded as a true lipase which also exhibits some esterase activity. This was confirmed by the observation that the ratios of these three activities remained essentially constant during the entire purification procedure [average ratios lipase/esterase ( $p$-nitrophenyl acetate)/esterase (Tween 80), 8.2:0.9:1.0], which also indicated that this enzyme was probably the only lipase/esterase present in the original culture supernatant.

Measurements of the effect of temperature and $\mathrm{pH}$ on the lipase and esterase (Tween 80) activities of the purified enzyme showed that maximal activities were observed at $50^{\circ} \mathrm{C}$, and at $\mathrm{pH} 8.5$ and 9.0 , respectively.

The enzyme exhibited a biphasic loss of lipase activity during exposure to high temperatures, with an initial $t_{\frac{1}{2}}$ of $17.5 \mathrm{~min}$ at $60^{\circ} \mathrm{C}$ (Fig. $2 a$ ). The extent of this initial inactivation phase varied with temperature, increasing from a $48 \%$ loss of activity at $55^{\circ} \mathrm{C}$ to a complete loss of activity at $80^{\circ} \mathrm{C}$. The effect of temperature was analysed in more detail by measuring the time taken (D, h; see Fox \& Stepaniak, 1983) for the enzyme to lose $90 \%$ of its activity during exposure to various temperatures (measured by extrapolation, as required, of the initial inactivation phase), and then replotting the log of the D values against temperature to determine the increase in temperature which was required to decrease $D$ by an order of magnitude (defined as $\mathrm{Z},{ }^{\circ} \mathrm{C}$; see Fox \& Stepaniak, 1983) (Fig. 2b). A $Z$ value of $9.75^{\circ} \mathrm{C}$ was obtained by this procedure.

The lipase was very stable to freezing and thawing, losing only $16 \%$ of its activity after six freeze-thaw cycles.

\section{Regiospecificity of lipase}

The regiospecificity of the Ps. aeruginosa lipase was determined by measuring the release of ${ }^{14} \mathrm{C}$-labelled dioleins, monooleins and oleic acid from $\left[{ }^{14} \mathrm{C}\right]$ triolein labelled in the $\mathrm{C}-1$ position of each of the fatty acyl 

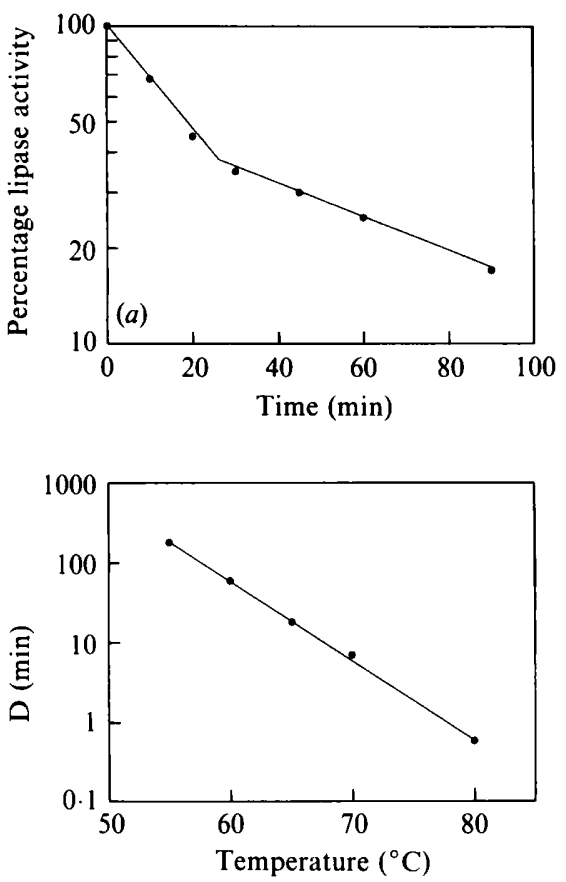

Fig. 2. Determination of the thermostability of the Ps. aeruginosa EF2 lipase. Purified lipase (approximately $20 \mu \mathrm{g} \mathrm{ml}^{-1}$ in $20 \mathrm{~mm}-\mathrm{Tris} / \mathrm{HCl}$ buffer, $\mathrm{pH} \mathrm{7.5)}$ was incubated at various temperatures over the range 55 to $80^{\circ} \mathrm{C}$. Samples were taken at regular intervals and assayed for lipase activity, and the $\mathrm{D}$ value (the time taken for the enzyme to lose $90 \%$ of its original activity measured by extrapolation of the initial rapid phase of inactivation) was calculated for each temperature. (a) Percentage lipase activity versus time of incubation at $60^{\circ} \mathrm{C},(b) \mathrm{D}$ versus temperature (slope $=Z$ ).

residues (Fig. 3). Slightly over half of the radioactivity in the triolein was released during the $7 \mathrm{~h}$ period of the experiment, the majority of which appeared in 1,2(2,3)diolein $(19 \%)$ and oleic acid $(23 \%)$, with much smaller amounts in 1,3-diolein $(6 \%)$ and monoolein $(4 \%)$. No detectable hydrolysis of triolein occurred in the absence of added lipase. It was concluded from these results that the lipase predominantly hydrolysed the peripheral $(1,3)$ ester bonds. This was confirmed by showing that lipase discriminated between a mixture of unlabelled dioleins ( $85 \%$ 1,3-diolein, $15 \%$ 1,2(2,3)-diolein), hydrolysing the 1,3-diolein much faster than the 1,2(2,3)-diolein.

\section{Sensitivity to inhibitors}

The divalent metal-chelating agent EDTA ( $1 \mathrm{~mm}$ ) caused no significant inhibition of lipase or esterase (Tween 80) activity following preincubation with the enzyme for $30 \mathrm{~min}$ at $30^{\circ} \mathrm{C}$, indicating that the enzyme is probably not a metalloprotein.

Preincubation of the enzyme with the serine-protease inhibitor DCI $(100 \mu \mathrm{M})$ at $30^{\circ} \mathrm{C}$ elicited a weak, time-

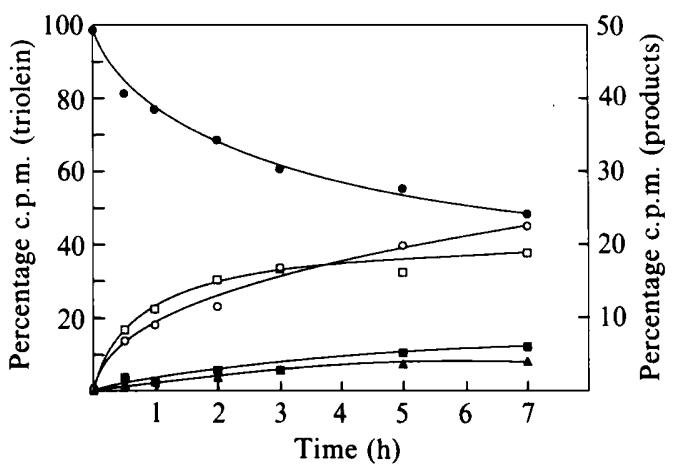

Fig. 3. Determination of the regiospecificity of the Ps. aeruginosa EF2 lipase on triolein. $\left[{ }^{14} \mathrm{C}\right]$ Triolein (glycerol tri $\left[1{ }^{-14} \mathrm{C}\right]$ oleate) was incubated with purified lipase (approximately $20 \mu \mathrm{g} \mathrm{ml}^{-1}$ ) at $37^{\circ} \mathrm{C}, \mathrm{pH} 8.5$, for $7 \mathrm{~h}$ and the concentrations of radiolabelled triolein, dioleins, monooleins and oleic acid were determined at various time intervals as described in Methods. 0 , Triolein; $\square, 1,2(2,3)$-diolein; $\square, 1,3$-diolein; $\Delta$, monooleins; $O$, oleic acid.

dependent, biphasic inhibition of lipase activity. The initial, fast rate of inactivation $(25 \%$ inhibition after 5 min incubation) was still extremely slow compared with the effect of DCI on serine proteases (Harper et al., 1985), and the subsequent slow phase rarely led to more than $50 \%$ inhibition even after $3 \mathrm{~h}$ incubation. DCI also had a similar effect on esterase (Tween 80 ) activity. It was not possible from these results to draw unambiguous conclusions with respect to the presence or absence of an essential serine residue in this enzyme.

\section{$N$-terminal amino acid sequence}

$\mathrm{N}$-terminal amino acid analysis of the Ps. aeruginosa EF2 lipase (Fig. 4) showed that the enzyme exhibited considerable similarity with the $\mathrm{N}$-terminal sequences of the lipases from $P s$. aeruginosa TE3285 (originally Ps. fluorescens), Ps. pseudoalcaligenes, Ps. sp. ATCC 21808, $P$ s. cepacia and Ps. fragi, as determined by direct analysis of the purified enzymes and/or from the DNA sequences of the cloned genes (Kugimiya et al., 1986; Aoyama et al., 1988; Nakanishi et al., 1989; Andreoli et al., 1989; Jørgensen et al., 1991; Kordel \& Schmid, 1991; Nishioka et al., 1991; T. Nishioka, personal communication). In spite of the failure to identify unambiguously the $\mathrm{N}$-terminal amino acid in the Ps. aeruginosa EF2 lipase, 11 of the next 12 amino acids were identical with those in the $P$ s aeruginosa TE 3285 enzyme, and at least five were identical with those in the other Pseudomonas enzymes. Several of the DNA sequences contained a region coding for a lengthy signal sequence, an observation which was commensurate with the extracellular nature of these lipases. All of the enzymes exhibited the consensus 


Ps. aeruginosa EF2
Ps. aeruginosa TE3285
Ps. pseudoalcaligenes
Ps. sp. ATCC 21808
Ps. cepacia M-12-33
Ps. cepacia DSM 3959
Ps. fragi

Ps. aeruginosa $\mathrm{EF} 2$

Ps. aeruginosa TE3285 G L F G

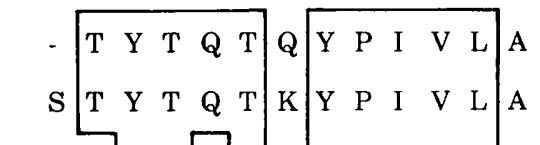

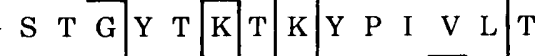

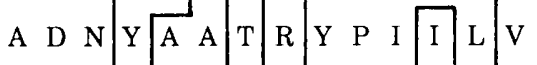

\begin{tabular}{lll|lll|lllll|l|l|l} 
A & $D$ & $N$ & $Y$ & A & $A$ & $T$ & $R$ & $Y$ & $P$ & $I$ & I & L & V
\end{tabular}

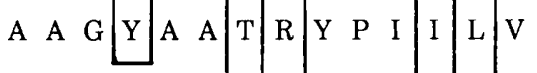

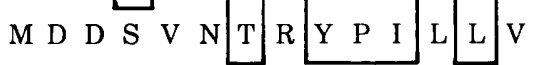

Fig. 4. Comparison of the N-terminal amino acid sequence of Ps. aeruginosa EF2 lipase with that of other bacterial lipases. The purification and $\mathrm{N}$ terminal amino acid sequencing of the Ps. aeruginosa lipase were carried out as described in Methods. The $\mathrm{N}$-terminal amino acid sequences of the other lipases were determined either by analysis of the purified enzyme or from the DNA sequence of the cloned lipase gene. Ps aeruginosa TE3285 (originally called Ps. fluorescens; Nishioka et al., 1991; T. Nishioka, personal communication), Ps. pseudoalcaligenes (Andreoli et al., 1989), Ps. sp. ATCC 21808 (Kordel \& Schmid, 1991), Ps. cepacia (Nakanishi et al., 1989; Jørgensen et al., 1991) and Ps. fragi (Kugimiya et al., 1986; Aoyama et al., 1988). sequence - TXYPIXL - close to the N-terminus, where the first variable residue was a basic amino acid (glutamine, arginine or lysine) and the second variable residue was a hydrophobic amino acid (isoleucine, leucine or valine).

\section{Discussion}

The essentially constant activity ratio for the hydrolysis of olive oil, $p$-nitrophenyl acetate and Tween 80 which was observed during the purification of the lipase from Ps. aeruginosa EF2, together with the approximately eightfold higher activity with the olive oil emulsion than with the two soluble substrates, confirmed that the enzyme is a true lipase which also exhibits some esterase activity (i.e. it preferentially hydrolyses ester bonds at fat-water interfaces). It is therefore appropriate to compare the properties of the purified lipase from $P s$. aeruginosa EF2 with those of other bacterial lipases, mainly, but not exclusively, from Pseudomonas spp. which have also been investigated (Dring \& Fox, 1983; Bozoğlu et al., 1984; Kugimiya et al., 1986; Stuer et al., 1986; Lee \& Iandolo, 1986; Yamamoto \& Fujiwara, 1988; Aoyama et al., 1988; van Oort et al., 1989).

The Ps. aeruginosa EF2 lipase, like all of these other bacterial lipases, is composed of a single type of subunit which can apparently undergo a variable degree of aggregation. The subunit $M_{\mathrm{r}}(29000)$ is very similar to that of several other Pseudomonas lipases (29000 to 35000 ), but substantially different from those reported for the Ps. fragi AFO 3458 (14600), Ps. fluorescens MC 50 (55000), Staphylococcus aureus (70000) and Staphylococcus hyicus (86000) enzymes (Bozoğlu et al., 1984; Kugimiya et al., 1986; Lee \& Iandolo, 1986; van Oort et al., 1989).

The observation that lipase activity was significantly enhanced in the presence of $\mathrm{CaCl}_{2}$ and $\mathrm{NaCl}$ probably reflects the ability of these salts to react with free fatty acids adhering to the oil droplets, to diminish interfacial charge effects and/or to increase droplet surface area (see Brockerhoff \& Jensen, 1974). In terms of lipase activity, the specific activity (6606 $\mathrm{LU} \mathrm{mg}^{-1}$ ) and the calculated $k_{\text {cat }}\left(3193 \mathrm{~s}^{-1}\right)$ of the purified enzyme from Ps. aeruginosa EF2 are two- to six-fold higher than those reported for the lipases from Ps. fluorescens, Pseudomonas sp., Pseudomonas sp. ATCC 21808 and S. hyicus (Dring \& Fox, 1983; Yamamoto \& Fujiwara, 1988; van Oort et al., 1989; Kordel \& Schmid, 1991), but lower than for the lipase from Ps. aeruginosa PAC1 R (Stuer et al., 1986), all measured under similar, but not identical, conditions.

The optimum $\mathrm{pH}$ for lipase and esterase activity ( $\mathrm{pH} \mathrm{8.5-9.0)} \mathrm{is} \mathrm{within} \mathrm{the} \mathrm{range} \mathrm{(} \mathrm{pH} 7 \cdot 0-9.5)$ exhibited by other Pseudomonas lipases, whereas the optimum temperature $\left(50^{\circ} \mathrm{C}\right)$ is significantly higher than that of the lipases from Ps. aeruginosa PAC1R, Pseudomonas sp., and a psychrotrophic strain of Ps. fluorescens $\left(<40^{\circ} \mathrm{C}\right)$ and lower than the lipase from Ps. fragi $(65-$ $80^{\circ} \mathrm{C}$ ). Importantly, the thermostability of the $P$ s. aeruginosa $\mathrm{EF} 2$ lipase at $60^{\circ} \mathrm{C}\left(t_{\frac{1}{2}} 17.5 \mathrm{~min}\right)$ is significantly greater than that of the other Pseudomonas lipases which have been examined in this way $\left(t_{\frac{1}{2}} 1-10 \mathrm{~min}\right)$ (Dring \& Fox, 1983; Fox \& Stepaniak, 1983; Yamamoto \& Fujiwara, 1988).

The insensitivity of the purified lipase to EDTA probably indicated that, in contrast to other Pseudomonas lipases (Dring \& Fox, 1983; Bozoğlu et al., 1984; Yamamoto \& Fujiwara, 1988), the lipase activity is not dependent on the presence of a divalent metal activator.

It is possible that both the relatively high thermostability and the resistance to inhibition by EDTA reflect the growth conditions under which $P s$. aeruginosa EF2 was isolated, i.e. at a relatively high temperature $\left(50^{\circ} \mathrm{C}\right)$ in an olive oil minimal medium supplemented with the chelating agent nitrilotriacetic acid (Gilbert et al., 1991).

The marked specificity of the Ps. aeruginosa EF2 lipase for the 1,3-oleyl residues of triolein is very similar to that previously observed for several fungal lipases, and 
contrasts with the lack of specificity exhibited by other fungal lipases and by the lipase from $S$. hyicus (Okumura et al., 1976; van Oort et al., 1989).

The N-terminal amino acid sequence of the Ps. aeruginosa EF2 lipase is strikingly similar to that of the other Pseudomonas lipases which have recently been sequenced, either by direct analysis of the purified enzymes or from the DNA sequences of the lipase genes (Kugimiya et al., 1986; Aoyama et al., 1988; Andreoli et al., 1989; Nakanishi et al., 1989; Jørgensen et al., 1991; Kordel \& Schmid, 1991; Nishioka et al., 1991), indicating that all of the enzymes are probably closely related to each other. As they include the Ps. fragi IFO 3458 and $P s$. fluorescens MC50 lipases, which have been reported to have subunit $M_{\mathrm{r}}$ values of 14600 and 55000 , respectively (Bozoğlu et al., 1984; Kugimiya et al., 1986), it must be concluded that these two enzymes contain a non $\mathrm{N}$ terminal deletion and addition, respectively. It should be noted that none of the Pseudomonas lipases show any Nterminal sequence similarity to the lipases from $S$. aureus and S. hyicus (Lee \& Iandolo, 1986; van Oort et al., 1989).

Several of the Pseudomonas lipases have been shown to contain the consensus sequence -GXSXG - at their putative active site (Kugimiya et al., 1986; Andreoli et al., 1989; Nakanishi et al., 1989; Jäger et al., 1991; Jørgensen et al., 1991) and/or to be inhibited by the serine-active reagent diethyl $p$-nitrophenyl phosphate (Jäger et al., 1991; Kordel \& Schmid, 1991), indicating that a serine residue is essential for lipase activity. The relatively slow and incomplete inhibition of the $P s$. aeruginosa $\mathrm{EF} 2$ lipase by the serine-active reagent DCI (compared with the effect of the latter on various serine proteases; Harper et al., 1985) was therefore rather unexpected, and suggests either that the enzyme does not contain a serine residue at its active site or, more likely, that serine residue is present but is relatively inaccessible to DCI.

The authors are indebted to Jan Drozd for useful discussions, to Maria Podlusiuk for initial help with the DCI work, and to Katherine Lilley for determining the $\mathrm{N}$-terminal amino acid sequence. This work was supported through the award of an SERC CASE studentship (to E. J. G.) in collaboration with Shell Research.

\section{References}

ANDReoli, P. M., CoX, M. M. J., FARIN, F. \& Wohlfarth, S. (1989). Molecular cloning and expression of genes encoding lipolytic enzymes. European Patent 0334462.

Aoyama, S., Yoshida, N. \& InouYe, S. (1988). Cloning, sequencing and expression of the lipase gene from Pseudomonas fragi IFO-12049 in E. coli. FEBS Letters 242, 36-40.

Bozơ̌lu, F., Swaisgood, H. E. \& ADAms, D. M. (1984). Isolation and characterisation of an extracellular heat-stable lipase produced by
Pseudomonas fluorescens MC 50. Journal of Agricultural and Food Chemistry 32, 2-6.

Brockerhoff, H. \& Jensen, R. G. (1974). Lipolytic Enzymes. New York: Academic Press.

Dring, R. \& Fox, P. F. (1983). Purification and characterisation of a heat-stable lipase from Pseudomonas fluorescens AFT 29. Irish Journal of Food Science and Technology 7, 157-171.

Fox, P. F. \& STEPANIAK, L. (1983). Isolation and some properties of extracellular heat-stable lipases from Pseudomonas fluorescens strain AFT 36. Journal of Dairy Research 50, 77-89.

GilberT, E. J., DrozD, J. W. \& Jones, C. W. (1991). Physiological regulation and optimization of lipase activity in Pseudomonas aeruginosa EF2. Journal of General Microbiology. 137, 2215-2221.

Hames, B. D. (1981). An introduction to polyacrylamide gel electrophoresis. In Gel Electrophoresis of Proteins, pp. 1-91. Edited by B. D. Hames \& D. Rickwood. Oxford: IRL Press.

Harper, J. W., Hemmi, K. \& Powers, J. C. (1985). Reaction of serine proteases with substituted isocoumarins: discovery of 3,4-dichloroisocoumarin, a new general mechanism based serine protease inhibitor. Biochemistry 24, 1831-1841.

HARWOOD, J. (1989). The versatility of lipases for industrial uses. Trends in Biochemical Sciences 14, 125-126.

JÄGER, K. E., WOHLFARTH, S. \& WINKLER, U. K. (1991). Extracellular lipase of Pseudomonas aeruginosa. In Lipases: Structure, Mechanism and Genetic Engineering (GBF monograph no. 16), pp 381-384. Edited by L. Alberghina, R. Verger \& R. D. Schmid. Weinheim: $\mathrm{VCH}$.

Jørgensen, S., Skov, K. W. \& Diderichsen, B. (1991). Cloning, sequence and expression of a lipase gene from Pseudomonas cepacia: lipase production in heterologous hosts requires two Pseudomonas genes. Journal of Bacteriology 173, 559-567.

KORDEL, M. \& SCHMID, R. D. (1991). Inhibition of the lipase from Pseudomonas sp. ATCC 21808 by diethyl $p$-nitrophenyl phosphate; hints for one buried active site for lipolytic and esterolytic activity. In Lipases: Structure, Mechanism and Genetic Engineering (GBF monographs no. 16). pp. 385-388. Edited by L. Alberghina, R. Verger \& R. D. Schmid. Weinheim: VCH.

KugimiYa, W., Otanis, Y., Hashimoto, Y. \& TAgaki, Y. (1986). Molecular cloning and nucleotide sequence of the lipase gene from Pseudomonas fragi. Biochemical and Biophysical Research Communications 141, 185-190.

LEE, C. Y. \& IANDolo, J. J. (1986). Lysogenic conversion of staphylococcal lipase is caused by insertion of the bacteriophage L54a genome into the lipase structural gene. Journal of Bacteriology 166, 385-391.

MACRAE, A. R. (1983). Extracellular microbial lipases. In Microbial Enzymes and Biotechnology, pp. 225-250. Edited by W. M. Fogarty. London: Applied Science Publishers.

Macrae, A. R. \& Hammond, R. C. (1985). Present and future applications of lipases. Biotechnology and Genetic Engineering Reviews 3, 193-217.

Nakanishi, J., Kurono, Y., Kolde, Y. \& Beppu, T. (1989). Recombinant DNA, bacterium of the genus Pseudomonas containing it, and process for preparing lipase using it. European Patent 0331376.

Nishioka, T., Chihara-Shiomi, M., Yoshikawa, K., Inagaki, M., Yamamoto, Y., Hiratake, J., BABA, N. \& OdA, J. (1991). Lipase from Pseudomonas sp.: reactions, cloning and amino acid sequence analysis. In Lipases: Structure, Mechanism and Genetic Engineering (GBF monographs No. 16), pp. 253-262. Edited by L. Alberghina, R. Verger \& R. D. Schmid. Weinheim: VCH.

Oxumura, S., IwaI, M. \& TsujisaKa, Y. (1976). Positional specificities of four kinds of microbial lipases. Agricultural and Biological Chemistry 40, 655-660.

VAN OORT, M. G., DeEver, A. M. T. J., DiJkman, R., TJeenk, M. L., VeRheis, H. M., De HAAS, G. H., Wenzig, E. \& GotZ, F. (1989). Purification and substrate specificity of Staphylococcus hyicus lipase. Biochemistry 28, 9278-9285.

Silman, N. J., Carver, M. A. \& Jones, C. W. (1989). Physiology of amidase production by Methylophilus methylotrophus: isolation of hyperactive strains using continuous culture. Journal of General Microbiology 135, 3153-3164. 
Silman, N. J., Carver, M. A. \& Jones, C. W. (1991). Directed evolution of amidase in Methylophilus methylotrophus: purification and properties of amidases from wild-type and mutant strains. Journal of General Microbiology 137, 169-178.

StUeR, W., JAEGer, K. E. \& WinkLer, U. K. (1986). Purification of extracellular lipase from Pseudomonas aeruginosa. Journal of Bacteriology 168, 1070-1074.

Yamamoto, K. \& Fujiwara, N. (1988). Purification and some properties of a castor-oil hydrolysing lipase from Pseudomonas sp. Agricultural and Biological Chemistry 52, 3015-3021. 